\title{
Evidence of sexuality in induced tetraploids of Brachiaria brizantha (Poaceae)
}

\author{
Ana Claudia Guerra Araujo ${ }^{1, *}$, Janine Machado Nóbrega ${ }^{1,2}$, Marisa Toniolo Pozzobon ${ }^{1}$ \\ \& Vera Tavares de Campos Carneiro ${ }^{1}$ \\ ${ }^{1}$ Embrapa Genetic Resources \& Biotechnology (Cenargen), Estação Biológica-PqEB - Final W5 Norte. CP 02372, \\ Brasilia, DF-70770-900, Brazil; ${ }^{2}$ Faculdade da Terra de Brasília-FTB, Recanto das Emas, DF-Brazil \\ (*author for correspondence: e-mail: guerra@cenargen.embrapa.br)
}

Received 27 October 2004; accepted 25 February 2005

Key words: apomixis, caryopses, chromosome, embryo sac, meiosis, ploidy

\section{Summary}

Difficulties in obtaining new breeding lines of Brachiaria (Trin.) Griseb., an important forage grass in Brazil, are mostly related to differences in ploidy among the accessions, and to apomixis, an asexual mode of reproduction. Usually, sexual accessions are diploid while apomicts are polyploid. Induced tetraploids of Brachiaria brizantha (A. Rich.) Stapf have been successfully obtained and this paper presents the results of a study of their reproductive modes and fertility. Despite frequent meiotic aberrations during microspore development, the induced tetraploids produced viable pollen and produced progeny after controlled self-pollination. Similarly to the original diploid sexual progenitor, embryo sacs of the Polygonum type with confirmed meiotic origin were present in the induced tetraploids suggesting chromosome doubling did not alter the reproductive mode. The embryo sac of the Polygonum type was also observed in progenies obtained after self and open pollination. Nevertheless, embryo sacs of the Polygonum and the Panicum types within the same ovule were observed in some progenies obtained after open pollination, probably having resulted from hybridization with tetraploid, apomictic plants. Indeed, the compatibility of the progeny with tetraploid, apomictic B. brizantha was confirmed by the formation of mature caryopses after controlled pollination. Evidence is presented that the induced tetraploids and their progeny are sexual plants and that they are compatible with natural tetraploid B. brizantha. The induced tetraploids will be useful for analyses of apomictic inheritance as well as in the development of sexual tetraploid lines in Brachiaria breeding programs.

\section{Introduction}

Genus Brachiaria (Trin.) Griseb. belongs to the family Poaceae and some species of this genus have been introduced from Africa to Brazil where they are cultivated as forage grass on an estimated 30-70 millions hectares (Macedo, 1995; Miles \& Valle, 1996). The existence of sexual and apomictic accessions of Brachiaria was detected through the analysis of the embryo sac structure in the accessions of different species (Valle, 1990). Apomixis is an asexual mode of reproduction that gives origin to plants genetically identical to the mother plant. It occurs through an autonomous development of the egg cell within an unreduced embryo sac in the gametophytic apomictic plants (Nogler, 1984; Asker \& Jerling, 1992; Savidan, 2000; Koltunow \& Grossniklaus, 2003; Bicknell \& Koltunow, 2004).

Two ploidy levels are predominantly found in Brachiaria: diploid $(2 n=2 x=18)$, associated with sexuality, and tetraploid $(2 n=4 x=36)$, associated with apomixis. In Brachiaria brizantha (A. Rich.) Stapf, one of the most important tropical forage species 
(Valle \& Savidan, 1996), only one sexual accession, BRA002747, has been identified and characterized among 274 apomictic accessions (Carnahan \& Hill, 1958; Valle, 1986; Valle, 1990; Valle \& Glienke, 1991; Valle \& Savidan, 1996; Penteado et al., 2000).

Segregation analysis in Brachiaria showed that the apomictic character is under the control of a single dominant locus while sexuality is recessive (Valle et al., 1994), similarly to other grasses (reviewed by Bicknell \& Koltunow, 2004). The suggested genotype for tetraploid apomicts in Brachiaria is Aaaa and for diploid sexuals, aa (Valle et al., 1994; Miles \& Escandon, 1997).

Morphological analyses of the embryo sac structure permit inferences on the reproductive mode in Brachiaria (Valle \& Savidan, 1996). Sexual plants have an embryo sac of the Polygonum type, with eight nuclei within seven cells (Gobbe et al., 1982a; Lutts et al., 1994; Dusi \& Willemse, 1999; Araujo et al., 2000). Apomictic plants have one or more aposporous embryo sacs of the Panicum type, with four cells: the egg cell, two synergids and the uninucleated central cell (Lutts et al., 1994; Dusi \& Willemse, 1999; Araujo et al., 2000). Some Brachiaria apomictic accessions may have one embryo sac of the Polygonum type associated or not with aposporous embryo sacs, indicative of facultative apomixis (Valle \& Savidan, 1996).

One of the main limitations in Brachiaria breeding programs is related to ploidy differences among the accessions and to the presence of an asexual mode of reproduction, which permits the apomictic accessions to be used only as pollen donors. Also, an apparent incompatibility among Brachiaria accessions is observed with high mortality of hybrids obtained after interspecific hybridization (Ndikumana, 1985; Ngendahayo, 1988; Valle \& Savidan, 1996).

An important strategy to improve the Brachiaria breeding program was the development of an induced tetraploid, sexual B. ruziziensis, the current basis of the program (Swenne et al., 1981; Gobbe et al., 1982b; Valle \& Savidan, 1996). Pinheiro et al. (2000) produced tetraploid $B$. brizantha using colchicine applied to in vitro plants of the diploid, sexual B. brizantha accession BRA002747 with the aim of increasing parental diversity in the Brachiaria breeding program and bringing in the agricultural advantages of B. brizantha.

The current paper discusses the reproductive mode and fertility of these induced tetraploid $B$. brizantha plants and their progeny. The results suggest that the tetraploids have maintained the sexual mode of reproduction of the diploids from which they originated, and indicate their self compatibility and compatibility with the natural tetraploid B. brizantha.

\section{Material and methods}

\section{Plant material}

Chromosome doubling of a diploid sexual accession BRA002747 of B. brizantha was accomplished by colchicine treatment of basal segments of in vitro grown plants (Pinheiro et al., 2000). The diploid, sexual accession BRA002747 of B. brizantha, the apomictic tetraploid accession BRA000591 - cultivar (cv.) Marandu - of $B$. brizantha and six individual induced tetraploid plants of $B$. brizantha $(2 n=4 x=36)$ designated $\mathrm{C} 14, \mathrm{C} 31, \mathrm{C} 35, \mathrm{C} 36, \mathrm{C} 41$ and $\mathrm{C} 48$ are maintained in the experimental field in Embrapa Genetic Resources and Biotechnology, Brasília-DF, Brazil. Progeny was obtained from plant $\mathrm{C} 14$ after self-pollination (plants $\# 1,4,9$ and 12) and open pollination (plants \#7, 8, $10,11,13-20)$. One progeny plant from open pollination of each induced tetraploid plants C31, C41, C42, C43 and C48 were kindly provided by Dr. C.B. do Valle, Embrapa Beef Cattle, Campo Grande, MS, Brazil and designated as plants \#31, 41, 42, 43 and 48, respectively.

\section{Morphology of mature embryo sacs in cleared ovules}

Pistils were isolated from flowers collected at anthesis or 1 day after anthesis. Around 40 mature pistils of each induced tetraploid plant C31, C35, C36 and C41, 300 pistils each of $\mathrm{C} 14$ and $\mathrm{C} 48$, and around 30 mature pistils of plants \#1, 4, 7, 10, 13, 14, 41-43 and 48 were isolated. Samples were fixed in a mixture of $40 \%$ formaldehyde:glacial acetic acid:50\% ethanol (5:5:90, $\mathrm{v} / \mathrm{v}$ ) for 4-24 h at room temperature, and either cleared in the Herr's modified clearing solution (Pozzobon \& Araujo, 1998) or phenol:methylsalicilate mixture gradually replaced over 3 days by a pure methylsalicilate. Pistils were whole-mounted on concave slides either in a drop of latic acid:phenol or methylsalicilate, depending on the method of clearing. Mature embryo sacs within the cleared ovules were morphologically characterized using the Normasky differential interference contrast microscopy (DIC) in a Zeiss Axiophot. 


\section{Morphology of the developing embryo sacs in sectioned ovules of the induced tetraploids C14 and C48}

Ovules of the induced tetraploid plants $\mathrm{C} 14$ and $\mathrm{C} 48$ were collected during pistil development, at points corresponding to the stages of megasporogenesis and megametogenesis (stages I, II and III and IV, respectively - see Araujo et al., 2000 for details of the developmental stages). Around 20 isolated ovules at each stage of each plant were fixed in a mixture of $40 \%$ formaldehyde:glacial acetic acid:50\% ethanol (5:5:90, v/v) for 4-24 $\mathrm{h}$ at room temperature, dehydrated in ethanol series (from $70 \%$ to $100 \%$ ), infiltrated and embedded in JB4 ${ }^{\circledR}$ plastic resin (Polysciences). Semi-thin sections (2-4 $\mu \mathrm{m}$ thick) of embedded ovules at different stages of the pistil development were obtained and stained with methylene blue-basic fuchsin for morphological assessment. Analyses and photography were done at the bright field microscopy using a Zeiss Axiophot.

\section{Meiotic chromosome pairing in $\mathrm{C} 14$ and $\mathrm{C} 48$}

Meiotic chromosomes were analyzed in young anthers fixed in a mixture of absolute ethanol and acetic acid $(3: 1, \mathrm{v} / \mathrm{v})$ for $24 \mathrm{~h}$ at room temperature and stored in $70 \%$ ethanol at $4{ }^{\circ} \mathrm{C}$, squashed in a drop of propioniccarmine solution ( $6 \%$ carmine in $45 \%$ propionic acid). Analyses of meiotic chromosomes were done in bright field and phase contrast using a Zeiss Axioskope.

\section{Pollen grain analyses in C14 and C48}

Pollen viability was estimated by the percentage of well-stained pollen grains after incubation in a glycerin:acetocarmine solution $(1: 1, \mathrm{v} / \mathrm{v})$. Approximately 1000 pollen grains per plant were analyzed. Pollen size was determined by measuring the diameters of 170 pollen grains per plant. The diameters were determined using the LSM program in the Zeiss LSM 410 Laser Scanning Microscope, and mean values were calculated.

\section{Chromosome counts}

Chromosome numbers were determined in mitotic metaphases of root meristems. Young root tips were pre-treated with a saturated solution of 1bromonaphtalene for $3 \mathrm{~h}$ at $16^{\circ} \mathrm{C}$, washed three times in water and fixed in a freshly prepared mixture of ethanol and glacial acetic acid (3:1, v/v) for $2 \mathrm{~h}$, hydrolyzed in
$5 \mathrm{~N} \mathrm{HCL}$ for $20 \mathrm{~min}$ at room temperature, washed and incubated in $20 \%$ (w/v) Pectinase from Rhizopus sp (Sigma) and 2\% (w/v) Cellulase from Aspergillus niger (Sigma) in a sodium citrate buffer, $\mathrm{pH} 4.8$ for $40 \mathrm{~min}$ at room temperature. Such samples were stained with Feulgen for 30 min macerated on a microscope slide in a drop of propionic carmine and gently heated. Chromosome counts were done under the bright field and phase contrast in Zeiss Axiovert 135 M.

\section{Estimates of plant fertility}

Approximately 1000 florets containing flowers at anthesis in each induced tetraploid plant were tested. The racemes containing these flowers were isolated with paper bags for 12 days. Bagged flowers were harvested, counted and the number of fully filled caryopses was determined. The fertility was expressed as a ratio of the number of full caryopses to the total number of flowers scored. Among the progeny, a similar procedure was performed with 1511, 669, 325, 2273, 5926 and 3660 florets of plants \#1, 4, 7, 14, 41 and 48, respectively. Approximately 154, 127, 189, 519, 1069, 423 self-pollinated flowers of plants \#1, 4, 7, 14, 41 and 48, respectively, were also isolated and their fertility determined as above. Plants \#14 and 41 (608 and 378 flowers in each, respectively) were pollinated with cv. Marandu to determine the fertility after cross-pollination.

\section{Results}

Morphology of mature embryo sacs in cleared ovules of the induced tetraploids

Analyses of cleared pistils of plants $\mathrm{C} 14$ and C48 showed $30 \%$ of aborted ovules, identified by their dehydrated, collapsed embryo sacs, or by ovules frequently showing oxalate crystals. Variations around this number were observed in all induced tetraploids, possibly as a consequence of different collection periods and locations.

All well developed ovules of the six $B$. brizantha induced tetraploids had mature embryo sac of the Polygonum type, morphologically similar to that present in the diploid, sexual plant (Figure 1a). No embryo sac of the Panicum type (Figure 1b), as found in natural tetraploid apomicts of $B$. brizantha, was observed among the induced tetraploids. Only one embryo sac of the Polygonum type was present in each ovule, located close to the micropyle pole and containing the egg cell, 


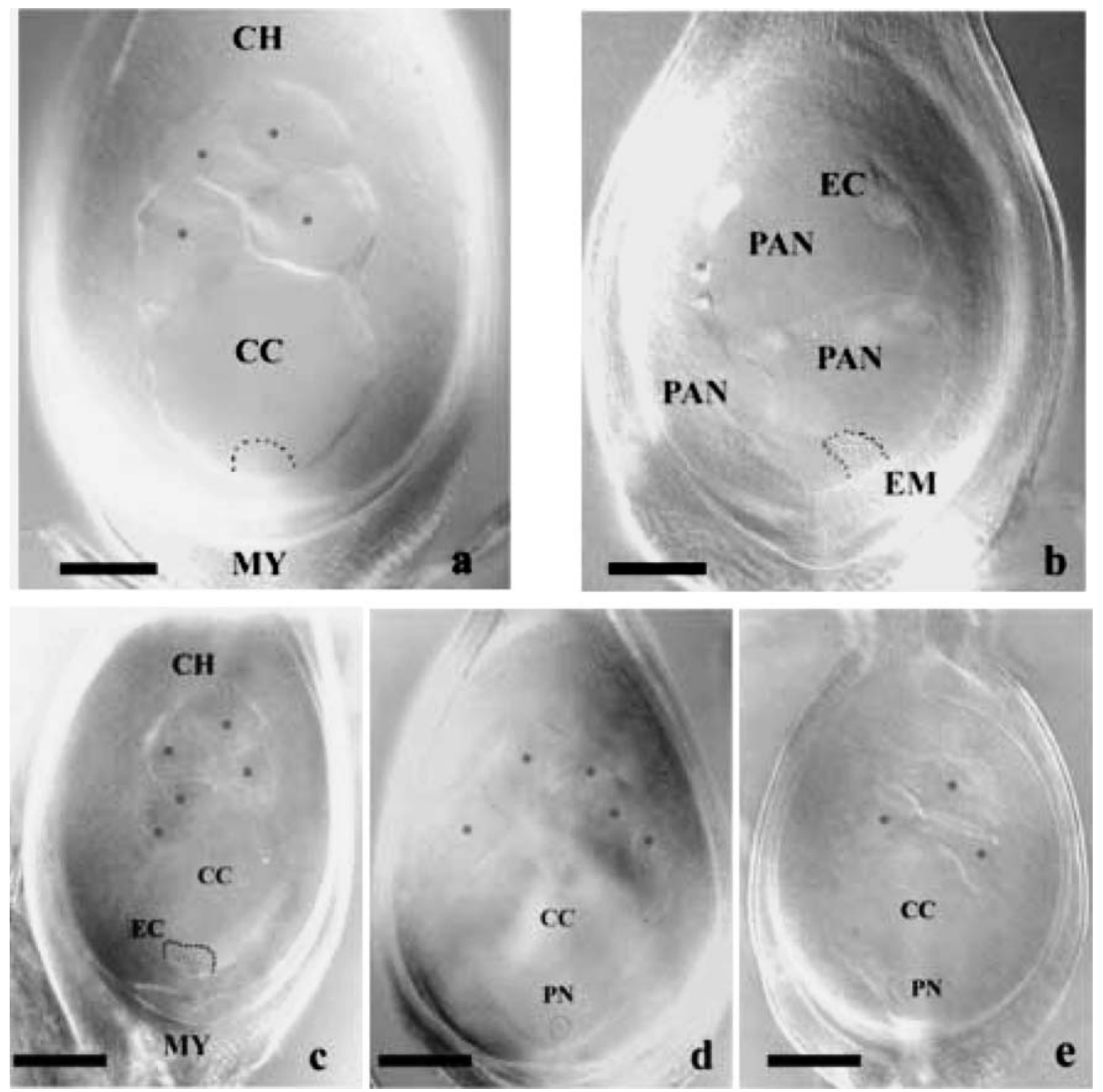

Figure 1. Micrographs of whole mounted cleared ovules of Brachiaria brizantha in showing the embryo sac. Micropyle (MY). Chalaza (CH). Egg cell apparatus (EC). Central cell (CC). Antipodal cells $\left(^{*}\right)$. (a) Diploid, sexual accession BRA002747 showing one embryo sac of the Polygonum type with four of the six antipodal cells in this plane of focus (bar corresponds to $600 \mu \mathrm{m}$ ). (b) Tetraploid, apomictic accession BRA000591 showing three embryo sacs of the Panicum type (PAN). Note the presence of an embryo (EM) within the embryo sac close to the micropyle pole, while in the chalazal embryo sac, the presence of the egg cell, identified by its cytoplasm is observed (bar corresponds to $600 \mu \mathrm{m}$ ). (c) Plant C35 (induced tetraploid) showing one embryo sac of the Polygonum type with five of the six antipodal cells in this plane of focus (bar corresponds to $500 \mu \mathrm{m}$ ). (d) Plant C48 (induced tetraploid) showing one embryo sac of the Polygonum type with two polar nuclei (PN) within the central cell and five of the six antipodal cells (bar corresponds to $500 \mu \mathrm{m}$ ). (e) Plant C41 (induced tetraploid) showing one embryo sac of the Polygonum type with two polar nuclei (PN) of the central cell and three of the six antipodal cells (bar corresponds to $600 \mu \mathrm{m}$ ).

two synergids, a large bi-nucleated central cell and six antipodal cells (Figures 1c-1e). The egg cell apparatus was always situated at the micropyle pole with the cytoplasm of the egg cell and the synergids evident while the nuclei were not easily detectable. Within the central cell, a large vacuole and two evident polar nuclei surrounded by dense cytoplasm were present in all plants (Figures 1d and 1e). Antipodal cells extended from the chalazal pole to the middle region of the embryo sac (Figures 1a and 1c-1e, Figures 2a and 2c). 

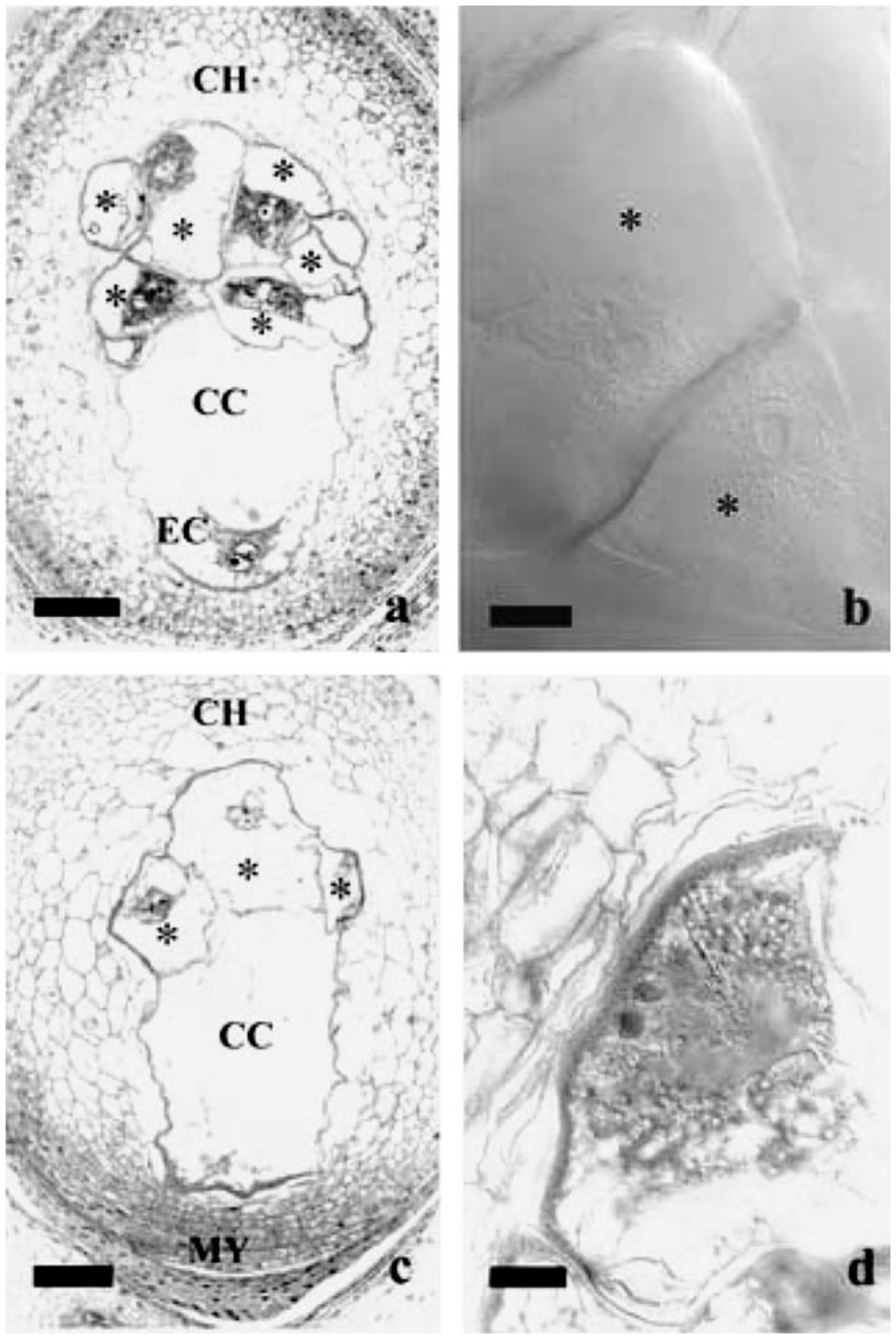

Figure 2. Micrographs of semi-thin sections of B. brizantha ovules (a, c and d) and a cleared ovule (b). Micropyle (MY). Chalaza (CH). Egg cell (EC). Central cell (CC). Antipodal cells (*). (a) Embryo sac of the Polygonum type in the diploid, sexual accession BRA002747 (bar corresponds to $200 \mu \mathrm{m}$ ). (b) Detail of two antipodal cells in the Polygonum type of embryo sac showing multiple nuclei surrounded by dense nucleoplasm and many vacuoles in the cell cytoplasm (bar corresponds to $200 \mu \mathrm{m}$ ). (c) Embryo sac of the Polygonum type in plant C48 (induced tetraploid) (bar corresponds to $400 \mu \mathrm{m}$ ). (d) Detail of one antipodal cell of plant C48 (bar corresponds to $400 \mu \mathrm{m}$ ).

Nuclei of these cells were different in shape and volume due to frequent nuclear divisions (Figures $2 b$ and 2d). The nuclei were always surrounded by dense cytoplasm (Figure 2). During earlier stages of the embryo sac development the antipodal cells in plants $\mathrm{C} 14$ and C48 had larger volumes relative to the diploid, sexual B. brizantha. However, the number of antipodal cells was always six and they showed similar volume, shape 
and spatial distribution in mature embryo sacs of the diploid and in the induced tetraploid plants (Figures 1 and 2).

\section{Morphology of the developing embryo sac in sectioned ovules of plants $\mathrm{C} 14$ and C48}

Sectioned ovules in the early stages of megasporogenesis showed one megaspore mother cell (MMC) identified as a large uninucleated cell with thick cell walls (Figure 3a). Bi-nucleated MMC and the resulting cells after meiosis, the megaspores, could be observed first as dyad and then as megaspore tetrads (Figure 3b). Degeneration of these cells was indicated by the presence of a dense and large intensely stained region (Figure 3c) where viable megaspores could be detected at earlier stages of ovule development. Indications of degenerating cells were associated with a large cell situated chalazally, corresponding to the surviving, or functional megaspore (Figures $3 \mathrm{c}$ and $3 \mathrm{~d}$ ). This megaspore, which was larger than the adjacent cells, had a large vacuole and thick cell wall (Figures $3 \mathrm{e}-3 \mathrm{~g}$ ). Only one surviving megaspore was present in each tetrad and there was no indication of the presence of initial cells of the aposporous embryo sac of the Panicum type. During megagametogenesis, the functional megaspore enlarged and divided mitotically, forming a multinucleated structure containing a large vacuole. Observations of differentiation of this structure into a typical embryo sac of the Polygonum type (Figures 3f-3i) confirm the meiotic origin of the embryo sacs, with each embryo sac easily identified as of the Polygonum type by the presence of a bi-nucleated central cell and dividing antipodal cells in the chalaza (Figures $3 \mathrm{f}$ and $3 \mathrm{~g}$ ). In other ovules, the abortion of the female reproductive structure could be detected from early until late stages of development.

\section{Meiosis in plants $C 14$ and C48}

Analyses of the metaphases I showed primarily bivalent (Figure 4a) and quadrivalent associations (Figure 4b).
Univalents were sporadically observed in both plants while trivalents were observed only in C48. Although quadrivalents tend to be frequent in autopolyploids, in the analyzed plants bivalents predominated, with $34 \%$ of the microsporocytes in both plants having $18 \mathrm{bi}$ valents (Table 1). Unequal chromosome segregation and micronuclei were observed both at anaphase and telophase I and II (Figures $4 \mathrm{c}$ and $4 \mathrm{~d}$ ). Micronuclei with polarity disorder (Figure 4c) and multipolar spindles (Figure 4d) were present, the later leading to the formation of polyads. In addition, precocious chromosome migration, chromosome stickiness, lagging chromosomes and the presence of bridges at anaphase and telophase I were also observed. Asynchronous chromosome distribution resulting in the displacement of the equatorial plate chromosome was observed at metaphase I and II. These abnormalities resulted in irregular cytokinesis, giving rise to tri-nucleated cells (Figure 4e). Also, morphologically altered microspore tetrads, numerical deviations in the microspores with polyads, cells with irregular sizes, failure of the cell wall development and unbalanced meiotic products were present (Figure 4f). These irregularities notwithstanding, regular microspore tetrads outnumbered the abnormal ones.

\section{Pollen grains and fertility of the induced tetraploids}

Pollen grains of plants $\mathrm{C} 14$ and $\mathrm{C} 48$ had mean diameters of $42.21 \pm 10.41 \mu \mathrm{m}$ and $42.15 \pm 5.28 \mu \mathrm{m}$, respectively and $85 \%$ of the pollen grains showed intense acetocarmine stainability. Among the tested flowers of induced tetraploids C14, C38 and C48 about 17\% developed fully filled caryopses. In C36 and C41, the corresponding percentage was about $23 \%$. C35 had an even higher fertility, with about $34 \%$ of fully filled caryopses.

\section{Chromosome counts among progeny}

Chromosome counts were done in four plants from controlled self pollination and in sixteen plants from

Table 1. Meiotic chromosome associations in the induced tetraploid plants C14 and C48 of Brachiaria brizantha at diakinesis and metaphase I

\begin{tabular}{lllllll}
\hline & & & \multicolumn{4}{c}{ Average chromosome associations (range) } \\
\cline { 4 - 7 } Plant & \multirow{2}{*}{ No. of chromosomes } & No. of cells analyed & I & II & III & IV \\
\hline C14 & 36 & 47 & $0.04(0-2)$ & $15.25(8-18)$ & 0 & $1.36(0-5)$ \\
C48 & 36 & 63 & $0.14(0-2)$ & $15.63(8-18)$ & $0.05(0-1)$ & $1.11(0-5)$ \\
\hline
\end{tabular}



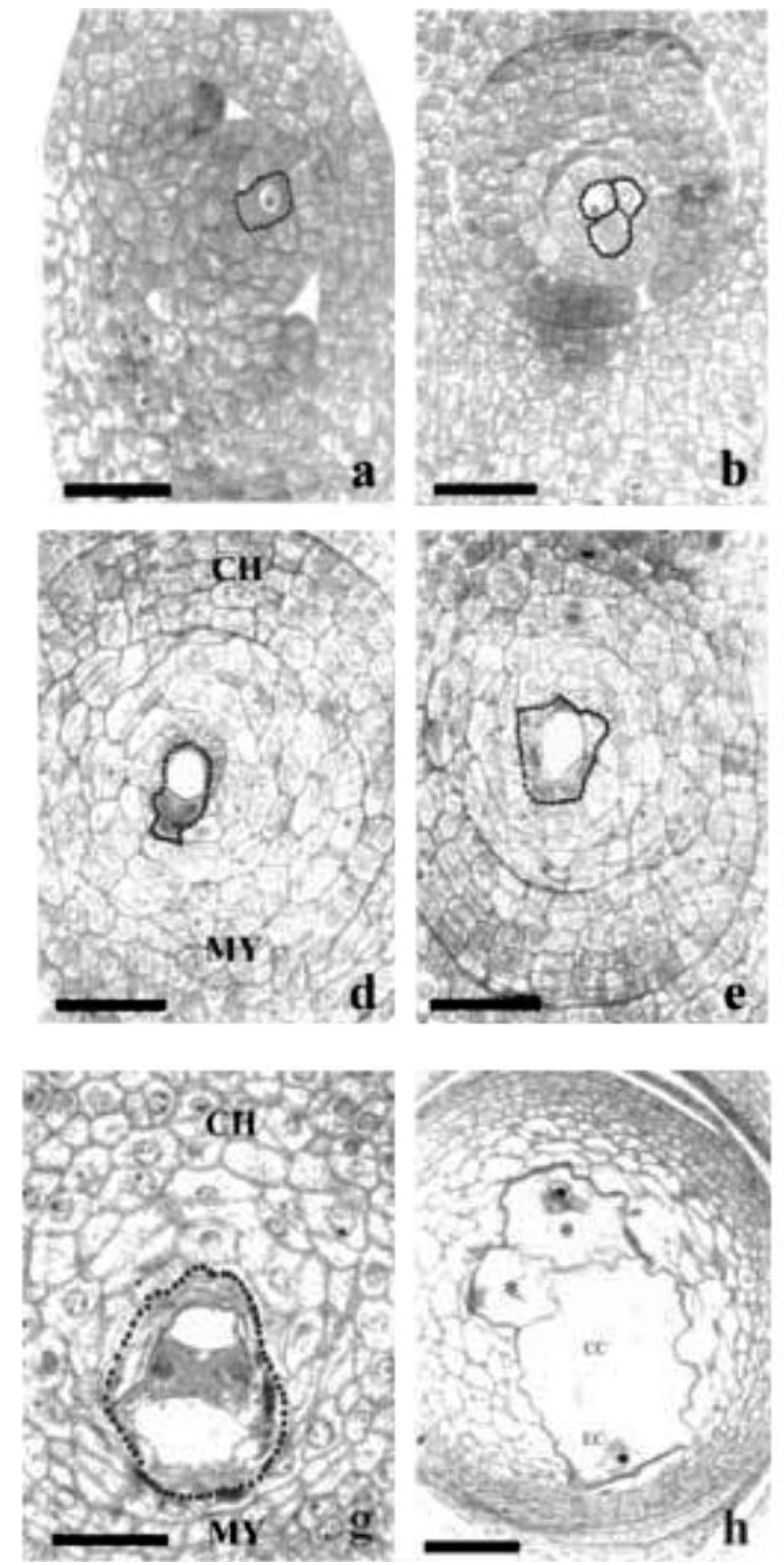
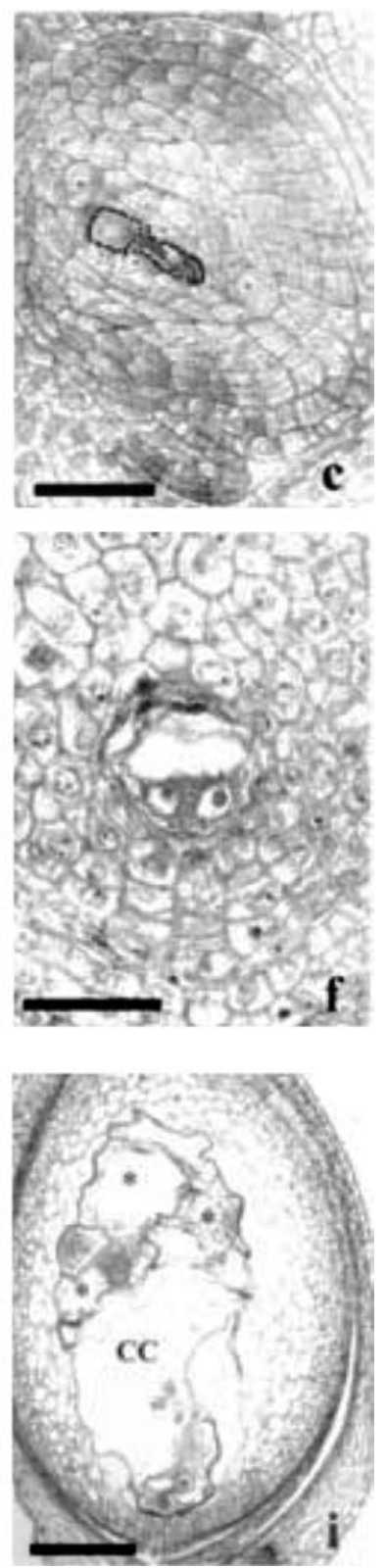

Figure 3. Micrographs of semi-thin sections of the induced tetraploid plants of B. brizantha ovules collected during megasporogenesis (a-e) and megagametogenesis (f-i). Micropyle (MY). Chalaza (CH). (a) An ovule of plant $\mathrm{C} 14$ collected at stage I showing the megaspore mother cell (the larger uninucleate cell with thick cell walls) (bar corresponds to $200 \mu \mathrm{m}$ ). (b) An ovule of plant C14 collected at stage I showing three of the four reduced megaspores which are not linearly displaced (bar corresponds to $200 \mu \mathrm{m}$ ). (c) An ovule of plant C48 collected at stage II showing degeneration of the megaspores (an irregularly-shaped intensely stained structure situated in the same place where megaspores are found at the earlier stages of development). Note one large cell with dense cytoplasm corresponding to the surviving megaspore (bar corresponds to $150 \mu \mathrm{m}$ ). (d) An ovule of plant C14 collected at stage II, showing the vacuole within the enlarged surviving megaspore and three degenerating megaspores (bar corresponds to $200 \mu \mathrm{m}$ ). (e) An ovule of plant C48 collected at stage II, showing the enlarged surviving megaspore surrounded by degenerating nucellar cells (bar corresponds to $100 \mu \mathrm{m}$ ). (f, g) Ovules of plant C14 collected at stage III showing the large functional megaspore with two of the four nuclei resulting from the mitosis. Note the presence of the vacuoles and the adjacent degenerating nucellar cells (bars correspond to $200 \mu \mathrm{m}$ ). (h) An ovule of plant C14 collected at stage IV showing one developing embryo sac of the Polygonum type containing the egg cell (EC), the central cell (CC) and the antipodal cells $\left(^{*}\right)$ (bar corresponds to $100 \mu \mathrm{m}$ ). (i) An ovule of plant C48 collected at stage IV showing one developing embryo sac of the Polygonum type with the egg cell apparatus, the central cell (CC) and the antipodal cells $\left(^{*}\right)$ (bar corresponds to $100 \mu \mathrm{m}$ ). 


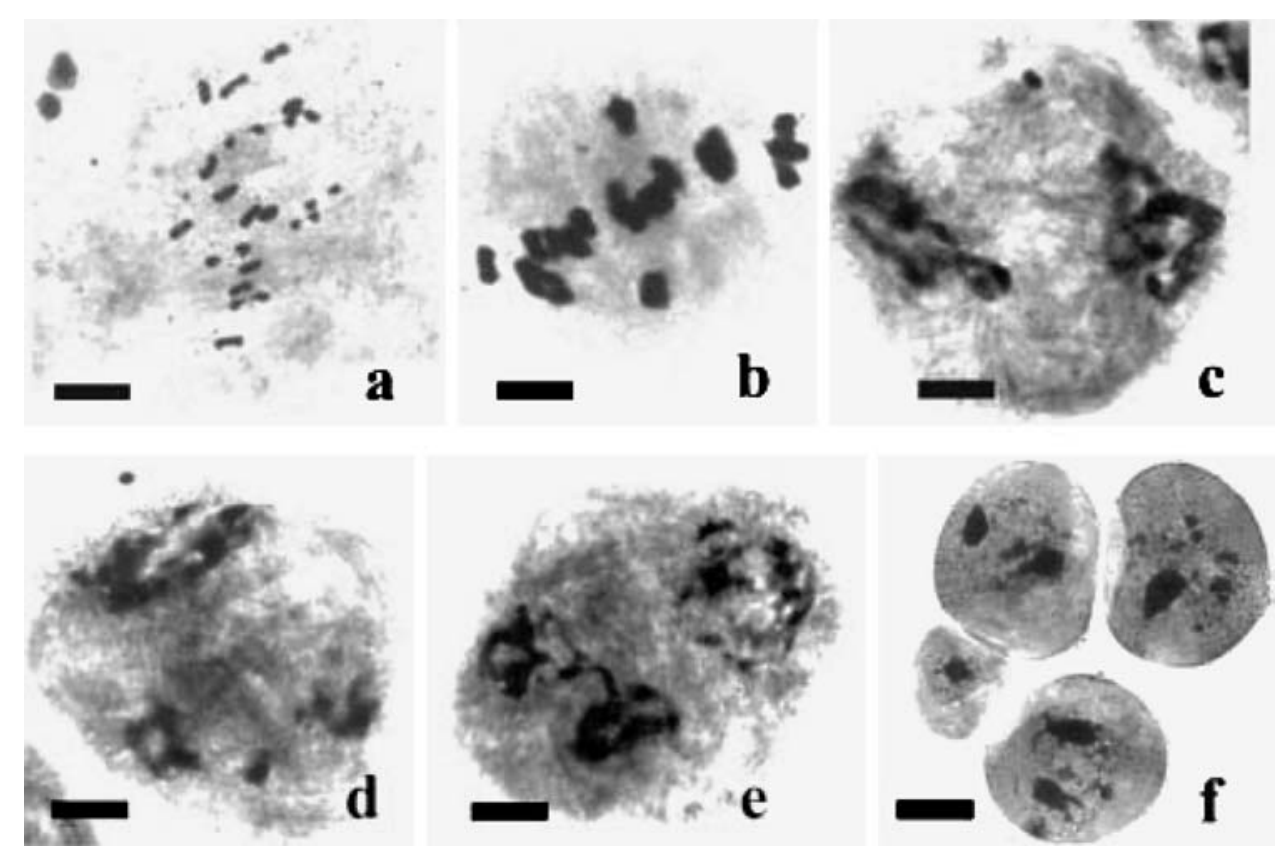

Figure 4. Meiosis in the B. brizantha induced tetraploid plants C14 and C48. Bivalent (a) and quadrivalent (b) associations (bars corresponds to $700 \mu \mathrm{m}$ ). (c) Micronuclei with polarity disorder (bar corresponds to $800 \mu \mathrm{m}$ ). (d) Multipolar spindles (bar corresponds to $800 \mu \mathrm{m}$ ). (e) One tri-nucleated cell (bar corresponds to $800 \mu \mathrm{m}$ ). (f) Cells with irregular size and polyads (bar corresponds to $800 \mu \mathrm{m}$ ).

open pollination. Among the progeny from self pollination one was tetraploid, three were triploid and none was diploid while among those from open pollination, six were tetraploid (Figure 5a), nine were triploid (Figure 5b) and one was diploid (Figure 5c).

\section{Observations of mature embryo sacs in cleared ovules}

Progeny plants obtained from the induced tetraploids showed $25-35 \%$ of aborted ovules. All well developed ovules of plants \#1, 4, 7, 10, 43 and 48 contained mature embryo sacs of the Polygonum type, morphologically similar to those found in the diploid, sexual plant and in the progenitor tetraploid plants (Figure 5d). No embryo sacs of the Panicum type were observed in these ovules. The well developed ovules of plants \#13,14, 41 and C42 that were produced by open pollination, showed within the same ovule one embryo sac of the Polygonum and one or more embryo sacs of the Panicum type (Figure 5e). The embryo sacs of the Panicum type showed the egg cell, two synergids and the uninucleated central cell, morphologically similar to the one found in apomictic Brachiaria sp.

\section{Estimates of fertility}

Fertility after open pollination was higher in $\mathrm{C} 41$ than in any other plant. Around $32 \%$ of the identified flowers in C41 showed fully filled caryopses while in plant \#1, the corresponding rate was $6 \%$, in plants \#4 and 7 it was $2 \%$, in plant \#14 it was $5 \%$, and in \#48,3\%. The fertility of plant \#41 was also higher in self pollination. In plants $\# 14$ and 1 , seed set was $2 \%$ and $1 \%$, respectively. In plants \#4, 7 and 48, no seeds were obtained after selfpollination. After controlled cross pollination (with $\mathrm{cv}$. Marandu), plant \#41 and 14 had 18\% and 5\% seed set, respectively.

\section{Discussion}

The inheritance of apomixis in Brachiaria has been reported to be simple and the trait to be conferred by a single dominant factor (Valle et al., 1994; Miles \& Escandon, 1997). Similar type of inheritance was reported in other aposporous apomictic grasses such as Pennisetum (Sherwood et al., 1994) and Panicum (Savidan, 1982), diplosporous such as Eragrostis curvula (Voigt \& Burson, 1981) and Tripsacum dactyloides (Leblanc et al., 1995) and in 


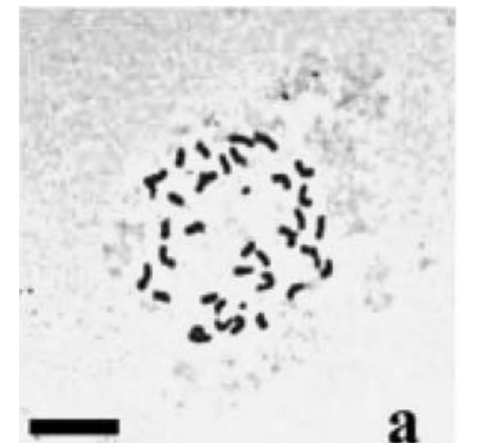

a
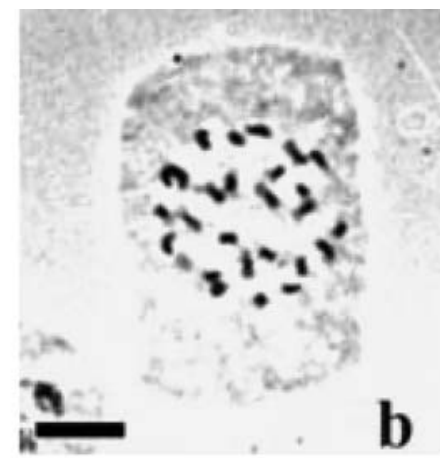

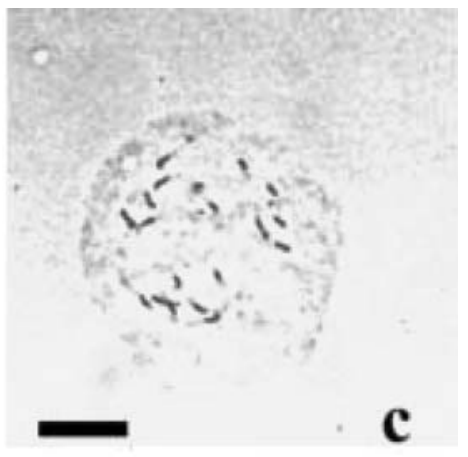

$\mathbf{c}$
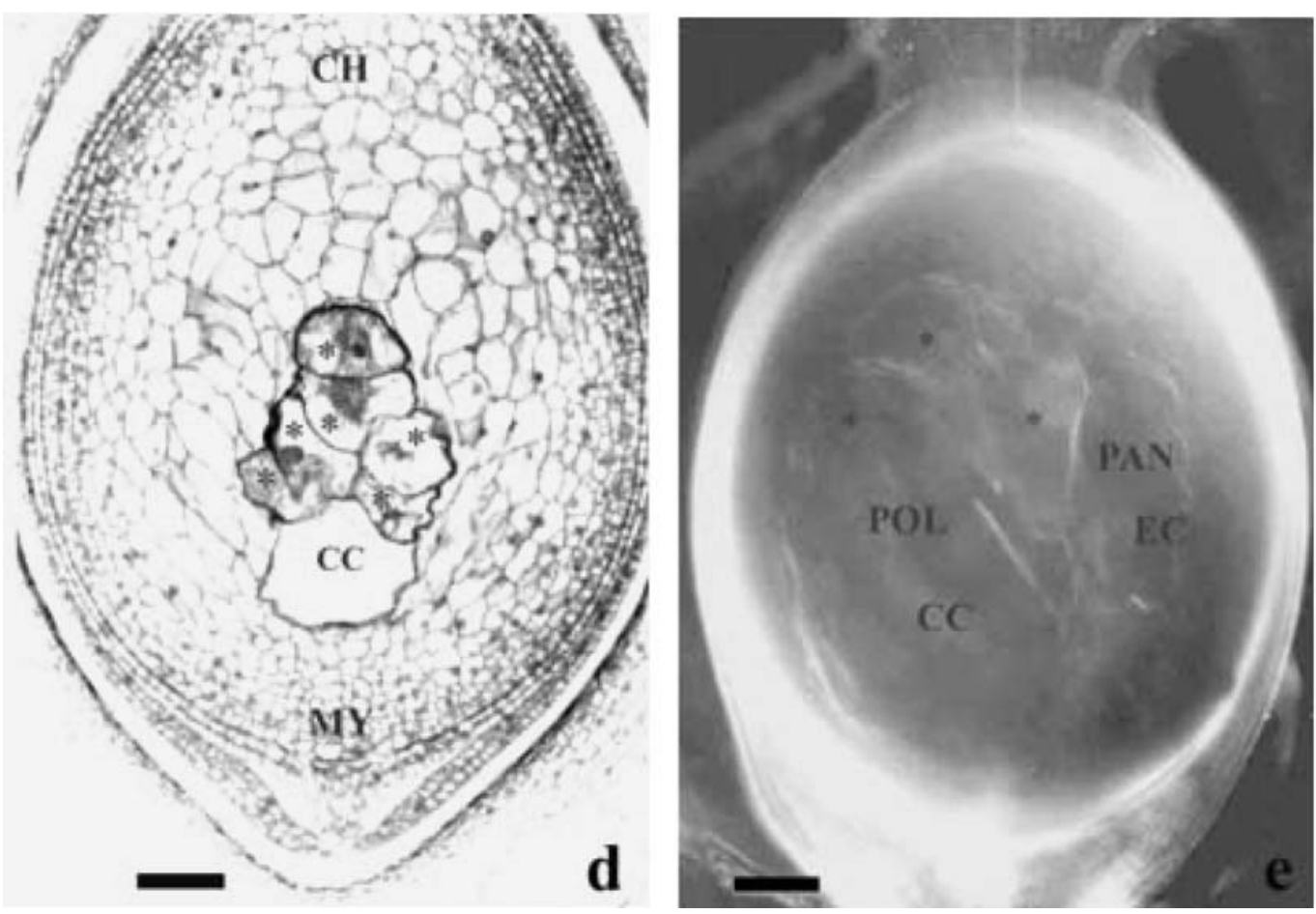

Figure 5. Mitotic metaphases of root meristems (a-c) and ovules of the progeny of the induced tetraploid B. brizantha (d, e). Embryo sac of the Panicum type (PAN) and Polygonum type (POL). Micropyle (MY). Chalaza (CH). Egg-cell apparatus (EC). Central cell (CC). Antipodal cells (*).Tetraploid plant \#14 (a), triploid plant \#7 (b) diploidy plant \#16 (c). (d) Semi-thin section of the ovule of plant \#4 with one embryo sac of the Polygonum type (POL). (e) Cleared ovule in plant \#14 with one embryo sac of the Panicum type (PAN) and one of the Polygonum type (POL). Three of the six antipodal cells are visible within the POL and the EC is observed within PAN (bars correspond to $700 \mu \mathrm{m}$ ).

dicotyledonous genera such as Ranunculus (Nogler, 1984) and Hieracium (Bicknell et al., 2000).

An association of apomixis with polyploidy is evident (Carman, 1997), although the apomictic mode of reproduction is not exclusive of polyploids. Rare diploid apomicts have been reported (reviewed by Savidan, 2000; Bicknell \& Koltunow, 2004). An analysis of induced autotetraploids Paspalum hexastachyum (Quarin \& Hanna, 1980), P. notatum (Quarin et al., 2001), and P. rufum (Quarin et al., 1998) indicated changes in the structure of the embryo sac, from the Polygonum to the Panicum type and, consequently, a possible change in the reproductive mode after chromosome doubling. Studies of induced tetraploid Paspalum suggested that genetic factors related to apomixis were present in the diploid genotype although expressed only at the tetraploid level. The failure of inducing apomixis in tetraploid Brachiaria could be due to the fact that although the genetic factors of apomixis may be present in a cryptic form at the diploid level, these 
might not have been present in the accessions used for chromosome doubling (Swenne et al., 1981; Pinheiro et al., 2000).

Based on the hypothesis that the apomictic character in Brachiaria is under the control of a single dominant allele, which is not present in sexual plants (Valle et al., 1994), apomixis would not be expected after the chromosome doubling of a sexual genotype $(a a)$. Here we confirm the presence and the meiotic origin of the embryo sac of the Polygonum type in the induced tetraploids of $B$. brizantha. Maintenance of the embryo sac structure and of the sexual reproductive mode was reported in induced tetraploids of $B$. ruziziensis (Gobbe et al., 1982a; Lutts et al., 1994). However, in B. ruziziensis, no natural tetraploid and apomictic accessions are known.

It is generally accepted that there is an overlap between apomixis and sexual development, and that the apomictic characteristics are an outcome of temporally and spatially altered regulation of the gene expression pathways (Koltunow \& Grossniklaus, 2003; Tucker et al., 2003). Indeed, in Brachiaria, the presence of the Polygonum type embryo sac, suggesting the occurrence of facultative apomixis (Valle et al., 1994; Valle \& Savidan, 1996; Araujo et al., 2000) may be indicative of this overlap. Additionally, similarities of the carbohydrate metabolism patterns (Dusi \& Willemse, $1999 b)$ and the presence of common cDNA sequences in different steps of the female reproductive development of apomictic and sexual Brachiaria were identified (Rodrigues et al., 2003).

A precocious enlargement of the antipodal cells was observed during the development of the embryo sac in the induced tetraploid relative to the sexual diploid accession, BRA002747 of B. brizantha. However, at maturity, the cells of the embryo sacs were identical in size, spatial distribution and shape.

The preservation of the embryo sac of the Polygonum type in induced tetraploids of B. brizantha as well as in their progeny indicate that these plants set seeds by a sexual process, similarly to the diploid accession BRA002747 from which they originated. Therefore, in contrast to the induced tetraploids of Paspalum sp (Quarin et al., 2001), in Brachiaria, the increase in gene dosage following chromosome doubling cannot by itself trigger the expression of the apomictic characteristics such as the formation of the aposporous embryo sac of the Panicum type.

Despite meiotic irregularities during pollen formation the majority of pollen mother cells showed bivalent associations, suggesting that fertile pollen could be produced. Additionally, the size of pollen grains and their viability, as measured by the acetocarmine stainability in the induced tetraploids C14 and C48, were similar to the fertile pollen in the diploid, sexual BRA002747 and in cv. Marandu (Alves, 2000). The ultimate evidence of fertility of the induced tetraploids was their seed set accomplished using these pollen grains. Irregular male meiosis of the induced tetraploids was similar to that observed in natural tetraploids of Brachiaria (Valle \& Savidan, 1996).

Notwithstanding the abnormalities, previous studies in B. brizantha cv. Marandu showed high levels of stained and regularly shaped pollen (Alves, 2000). The presence of viable pollen grains in the apomictic accessions of Brachiaria might dictate a strategy for the success of seed development, since these plants are pseudogamous apomicts. Endosperm formation depends on the fertilization of the central cell as demonstrated by the failure of caryopsis development in pistils which stigmas were incised before anthesis by Ngendahayo (1998). This was later confirmed by Alves et al. (2001) with the observations of the nuclear fusion and the endosperm ploidy levels. In fact, cv. Marandu propagates by seeds (Hopkinson et al., 1996), which are likely originated from self-pollination.

The similarity in the meiotic chromosome behavior during microsporogenesis and microgametogenesis and the pollen grain viability in the natural and induced tetraploids of $B$. brizantha suggest that the evolutionary origin of the natural tetraploids could be through self-polyploidization. This was suggested for $P$. rufum based on a cytogenetic analysis of triploid and tetraploid hybrids and of induced tetraploids (Quarin et al., 1998). Genetic analyses using molecular markers will be conducted to verify the origin of the tetraploid genome in B. brizantha.

A progeny showing the Panicum and the Polygonum type embryo sacs within the same ovule might be a result of intraspecific hybridization with an apomictic tetraploid. Cv. Marandu represents a potential pollen donor since it produced large amounts of viable pollen grain (Alves et al., 2000) during the flowering period of the induced tetraploid. Indeed, fully filled caryopses were obtained after controlled pollinations of the progeny with the cv. Marandu pollen, confirming the fertility and the sexuality of the progeny and suggesting an intraspecific compatibility. These plants are currently being used as females to generate a hybrid population for the analyses of the segregation of apomixis. The production of stable tetraploid, sexual $B$. brizantha represents a new perspective for the 
Brachiaria breeding program, where all known natural tetraploids are apomictic and only one induced tetraploid, sexual B. ruziziensis is available (Swenne et al., 1981).

\section{Acknowledgments}

We would like to thank A. A. Pinheiro and R. Fonseca for collaboration in different parts of this work during their undergraduate stage, Dr. C.B. do Valle for providing some plants, R. Falcão for technical assistance. Embrapa, CBAB/Ministry of Science and Technology and CNPq supported this research. J.M.N. thanks PIBIC/CNPq/Embrapa for an undergraduate fellowship.

\section{References}

Alves, E.R., 2000. Biologia reprodutiva de Brachiaria brizantha cv. Marandu. M.Sc. Thesis. University of Brasília, Brasília-DF, Brazil, p. 94.

Alves, E.R., V.T.C. Carneiro \& A.C.G. Araujo, 2001. Direct evidence of pseudogamy in an apomictic Brachiaria brizantha (Poaceae). Sex Plant Reproduc 14: 207-212.

Asker, S.E. \& L. Jerling, 1992. Apomixis in Plants, CRC Press Inc., Boca Raton, FL.

Araujo, A.C.G., S. Mukhambetzhanov, M.T. Pozzobon, E.F. Santana \& V.T.C. Carneiro, 2000. Female gametophyte development in apomictic and sexual Brachiaria brizantha (Poaceae). Rev Cytol Biol Veg - Le Botaniste Tome XXIII: 13-28.

Bicknell, R.A., N.K. Borst \& A. Koltunow, 2000. Monogenic inheritance of apomixis in two Hieracium species with distinct developmental mechanisms. Heredity 84: 228-837.

Bicknell, R.A. \& A.M. Koltunow, 2004. Understanding apomixis: Recent advances and remaining conundrums. Plant Cell 16: S228-S245.

Carman, J.G., 1997. Asynchronous expression of duplicate genes in angiosperms may cause apomixis, bispory, tetraspory, and polyembryony. Biol J Linn Soc 61: 51-94.

Carnahan, H.L. \& H.D. Hill, 1958. Apomxis in the Gramineae: Panicoideae. Am J Bot 54: 253-253.

Dusi, D.A.A. \& M.T.M. Willemse, 1999. Apomixis in Brachiaria decumbens Stapf.: Gametophytic development and reproductive calendar. Acta Biol Cracov Soc Bot 41: 151-162.

Dusi, D.M.A. \& M.T.M. Willemse, 1999b. Activity and localisation of sucrose synthase and invertase in ovules of sexual and apomictic Brachiaria decumbens. Protoplasma 208: 173-185.

Gobbe, J., A. Swenne \& B.-P. Louant, 1982a. Diploïdes naturels et autotetraploïdes induits chez Brachiaria ruziziensis Germain et Evrard: criteres d' identification. Agron Trop 36: 339-346.

Gobbe, J., B. Longly \& B.-P. Louant, 1982b. Calendrier des sporogénèses et gamétogénèses femelles chez le diploïde et le tétraploïde induit de Brachiaria ruziziensis (Graminée). Can J Bot 60: 2032-2036.
Hopkinson, J.M., F.H.D. de Souza, S. Diugheroff, A. Ortiz \& M. Sanchez, 1996. Reproductive physiology, seed production, seed quality of Brachiaria. In: J.W. Miles, B.L. Maass \& C.B. do Valle (Eds.), Brachiaria: Biology, Agronomy, and Improvement, pp. 124-140. CIAT, Colombia.

Koltunow, A.M. \& U. Grossniklaus, 2003. Apomixis: A developmental perspective. Ann Rev Plant Biol 54: 547-574.

Lutts, S., J. Ndikumana \& B.-P. Louant, 1994. Male and female sporogenesis and gametogenesis in apomictic Brachiaria brizantha, Brachiaria decumbens and F1 hybrids with sexual colchicine induced tetraploid Brachiaria ruziziensis. Euphytica 78: 1925.

Leblanc, O., M. Dueñas, M. Hernández, S. Bello, V. Garcia, J. Berthaud \& Y. Savidan, 1995. Chromosome doubling in Tripsacum: The production of artificial, sexual tetraploid plants. Plant Breed 114: 226-230.

Macedo, M.C.M., 1995. Pastagens no ecossistema cerrados: Pesquisas para o desenvolvimento sustentável. Proceedings of the Simpósio sobre pastagens nos ecossistemas brasileiros: Pesquisas para o desenvolvimento sustentável, Brasília-DF pp. 2862.

Miles, J.W. \& M.L. Escandon, 1997. Further evidence on the inheritance of reproductive mode in Brachiaria. Can J Plant Sci 77: 105-107.

Miles, J. \& C.B. do Valle, 1996. Manipulation of apomixis in Brachiaria breeding. In: J.W. Miles, B.L. Maass \& C.B. do Valle (Eds.), Brachiaria: Biology, Agronomy, and Improvement, pp. 147-163. CIAT, Colombia.

Ndikumana, J., 1985. Étude de l'hibridation entre espèces apomitiques et sexuées dans le genre Brachiaria. Ph.D. Thesis, Louvainla-Neuve, Universitè de Louvain, Belgium. p. 210.

Ngendahayo, M., 1988. Mécanismes de la réproduction dans le genre Brachiaria Gris. et stratégies d'amélioration et de séléction. Université Catholique de Louvain. Belgium. Ph.D. Thesis, p. 165.

Nogler, G.A., 1984. Gametophytic apomixis. In: B.M. Johri (Ed.), Embriology of Angiosperms, pp. 475-518. Springer-Verlag, Berlin.

Penteado, M.I.O., A.C.M. Santos dos, J.F. Rodrigues, C.B. Valle do, M.A.C. Seixas \& A. Esteves, 2000. Determinação de ploidia e quantidade de DNA em diferentes espécies do gênero Brachiaria. Boletim de Pesquisa 11 p. 31, Campo Grande: Embrapa-CNPGC.

Pinheiro, A.A., M.T. Pozzobon, C.B. Valle, M.I.O. Penteado \& V.T.C. Carneiro, 2000. Duplication of the chromossome number of diploid Brachiaria brizantha plants using colchicine. Plant Cell Rep 19: 274-278.

Pozzobon, M.T. \& A.C.G. Araújo, 1998. Técnica de clareamento modificada na análise de sacos embrionários em Brachiaria $e$ Paspalum (Gramineae) através da microscopia interferencial. Boletim de Pesquisa 3, p. 17. Brasília: Embrapa Recursos Genéticos e Biotecnologia.

Quarin, C.L., F. Espinoza, E.J. Martinez, S.C. Pessino \& O.A. Bovo, 2001. A rise of ploidy level induces the expression of apomixis in Paspalum notatum. Sex Plant Reproduc 13: 243-249.

Quarin, C.L. \& W.W. Hanna, 1980. Effect of three ploidy levels on meiosis and mode of reproduction in Paspalum hexastachyum. Crop Sci 20: 69-75.

Quarin, C.L., G.A. Norrmann \& F. Espinoza, 1998. Evidence for autoploidy in apomictic Paspalum rufum. Hereditas 129: 119124.

Rodrigues, J.C.M., G.B. Cabral, D.M.A. Dusi, L.V. Mello, D. Rigden \& V.T.C. Carneiro, 2003. Identification of differentially expressed 
cDNA sequences in ovaries of sexual and apomictic plants of Brachiaria brizantha. Plant Molec Biol 53: 745-757.

Savidan, Y., 1982. Nature et heredité de l'apomixie chez Panicum maximum Jacq. Travaux et Documents de L'ORSTOM. 153, p. 159.

Savidan, Y., 2000. Apomixis: Genetics and breeding. Plant Breed Rev 18: 13-86

Sheerwood, R.T., C.C. Berg \& B.A. Young, 1994. Transfering apomixis to maize. In: G.S. Khush (Ed), Apomixis: Exploiting Hybrid vigour in Rice, pp. 23-29. International Rice Research Institute, Manila, Phillippines.

Swenne, A., B.-P. Louant \& M. Dujardin, 1981. Induction par la colchicine de formes autotetraplö̈des chez Brachiaria ruziziensis Germain et Evrard (Graminée). Agron Trop 36: 134-141.

Tucker, M.R., A.C.G. Araujo, N. Paech, V. Hecht, E.D.L. Schmidt, J.-B. Rossel, S.C. De Vries \& A.M.G. Koltunow, 2003. Sexual and apomictic reproduction in Hieracium subgenus Pilosella are closely interrelated developmental pathways. Plant Cell 15: 15241537.
Valle, C.B. do, 1986. Cytology, mode of reproduction and forage quality of selected species of Brachiaria Griseb. Ph.D. Thesis, University of Illinois, IL, 90 p.

Valle, C.B. do, 1990. Coleção de germoplasma de espécies de Brachiaria no CIAT: Estudos básicos visando ao melhoramento genético. Documentos 46 p.33. Campo Grande: Embrapa CNPGC.

Valle, C.B. do \& C. Glienke, 1991. New sexual accessions in Brachiaria. Apo News 13: 11-13.

Valle, C.B. do, C. Glienke \& G.O.C. Leguizamon, 1994. Inheritance of apomixis in Brachiaria, a tropical forage grass. Apo News 17 : 42-43.

Valle, C.B. do \& Y. Savidan, 1996. Genetics, cytogenetics and reproductive biology of Brachiaria. In: J.W. Miles, B.L. Maass \& C.B. do Valle (Eds.), Brachiaria: Biology, Agronomy, and Improvement, pp. 147-163. CIAT, Colombia.

Voigt, P.W. \& B.L. Burson, 1981. Breeding of apomictic Eragrostis curvula. 14th International Grasslands Congress. Lexington Ky. pp. 160-163. 